\section{The realities of authoritarian media in China}

Media Commercialisation and Authoritarian Rule in China, Daniela Stockman. Cambridge, UK: Cambridge University Press, 2012. XXII+338pp. ISBN 978-1-107-01844-0

$\mathrm{C}$ HINA can no longer be called Communist. It is an authoritarian state in which a party that likes to call itself Communist maintains a firm grip on the country.

However much the party and the corrupt party princelings enjoy the benefits of capitalism (and let us be frank that it is a distinctively 19th century robber baron style of capitalism), the government uses methods of media control that have not changed since Mao took power in 1959. Censorship has always been part of the regime, but Mao and his direct successors were always clever enough to give the masses a chance to let off steam now and then through such projects as the Hundred Flowers campaign and the Democracy Wall movement.

Once enough steam had been released, the lid was screwed firmly back down. Real protest, such as the Tiananmen Square protests, were ruthlessly crushed.

Daniela Stockman argues that the current regime uses the same policies

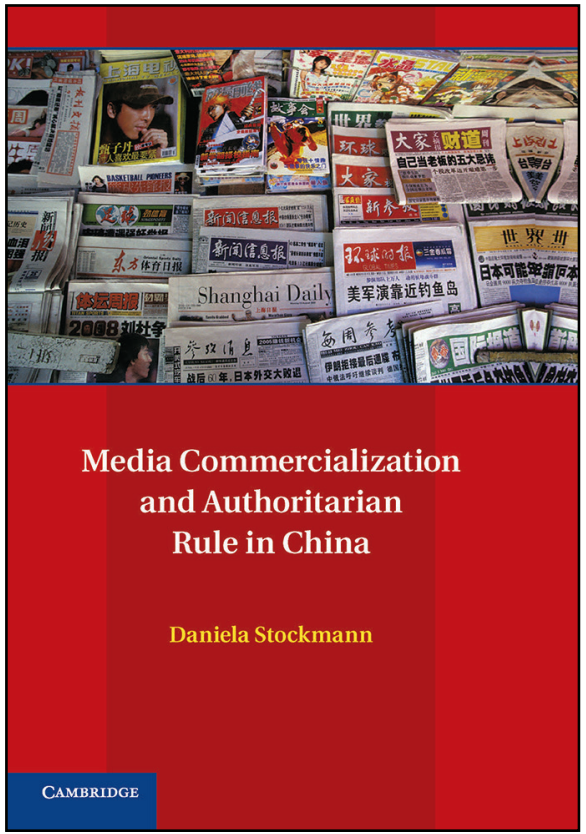

through what appears at first to be privately owned, non-government media. Her view is that it is precisely the non-government media which are the best tool for reinforcing the party line. Because people have learned not to trust party propaganda they prefer to read non-government newspapers, thinking they are more free.

As I discovered while doing research for this book, many other authoritarian states have followed a strategy similar to China's by introducing market forces into previously tightly controlled state media. When I started this project I was convinced that the introduction of such market forces had diversified and liberalised the Chinese media. My initial plan was to examine how commercial liberalisation of the media could contribute to political liberalisation and possibly democratisation; but the more data I gathered, the more evidence I found that 
the reverse was the case: while market forces brought about greater space for news reporting, this space turned out to the advantage of the regime, under the condition that institutions tighten the leash on the media when necessary. Overall, the balance between liberalisation and control promoted regime stability rather than diluted it. (p. Xv)

As happens in many parts of the world, the private press may be free, but it knows where the red lines are and rarely, if ever, crosses them. (The press in the United Arab Emirates, for instance, provides an excellent comparison with the Chinese situation). All the government has to do is to feed its line to the non-government press and people will think they are receiving an independent view. The government simply allows the press more leeway to report on matters that do not challenge its authority.

Meanwhile, the press can be allowed to gripe about matters that do not charge the party's authority and create an illusion of greater freedom.

The government, however, also plays some fairly dangerous games. It manipulates public feelings on international matters, especially towards Japan and the United States. The latter country is seen as China's main super power rival in the Pacific, so it can be criticised, but at the same time many Chinese in the capital and special economic zones who are familiar with the material output of American capitalism, see it as something to be envied.

Japan has been the target for fierce, even violent, nationalist sentiment because of its refusal to apologise for its invasion of China and the countless war crimes committed between 1937 and 1945. This rage, however, can also boil over into anti-government sentiment, so it is always controlled. Those who remember the devastation caused by the Cultural Revolution have no wish to see mobs of violent hooligans let loose again.

With Mao conveniently turned into a demi-God, the Cultural Revolution buried as deeply as the Tiananmen Square massacre and President Xi Jinping busy creating his own cult of personality, any claims by the current regime to have inherited the mantle of the Great Helmsman have little legitimacy. Nationalism, on the other hand, may provide a handy substitute for party loyalty, as long as it is carefully controlled.

However, as Stockman points out, popular nationalism, as opposed to government ordained sentiment, may contain elements of anti-government sentiment, especially with regard to foreign relations.

Thus the media, although supposedly independent and free, operates within unstated, but definite boundaries. Precisely because they appear to be free, the non-government press in fact provides legitimacy to government politics and control.

Daniela Stockman's work is highly recommended to those interested in China and its media and to those with a general interests in what happens when a Communist regime appears, at least outwardly, to have adopted capitalism. 